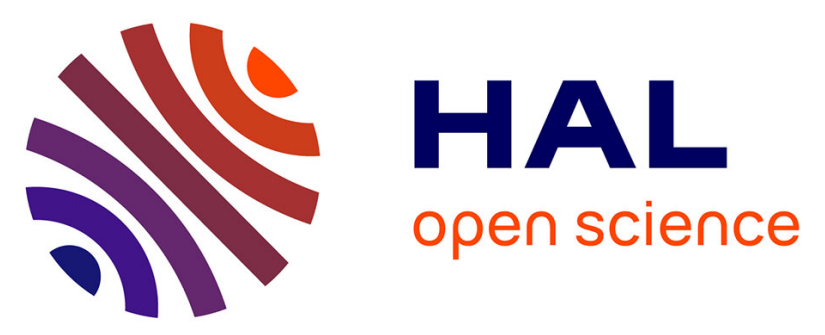

\title{
RET and GDNF mutations are rare in fetuses with renal agenesis or other severe kidney development defects
}

Cécile Jeanpierre, Guillaume Macé, Mélanie Parisot, Vincent Morinière, Audrey Pawtowsky, Marion Benabou, Jelena Martinovic, Jeanne Amiel, Tania Attié-Bitach, Anne-Lise Delezoide, et al.

\section{To cite this version:}

Cécile Jeanpierre, Guillaume Macé, Mélanie Parisot, Vincent Morinière, Audrey Pawtowsky, et al.. RET and GDNF mutations are rare in fetuses with renal agenesis or other severe kidney development defects. Journal of Medical Genetics, 2011, 48 (7), pp.497. 10.1136/jmg.2010.088526 . hal-00622876

\section{HAL Id: hal-00622876 https://hal.science/hal-00622876}

Submitted on 13 Sep 2011

HAL is a multi-disciplinary open access archive for the deposit and dissemination of scientific research documents, whether they are published or not. The documents may come from teaching and research institutions in France or abroad, or from public or private research centers.
L'archive ouverte pluridisciplinaire HAL, est destinée au dépôt et à la diffusion de documents scientifiques de niveau recherche, publiés ou non, émanant des établissements d'enseignement et de recherche français ou étrangers, des laboratoires publics ou privés. 


\title{
$R E T$ and $G D N F$ mutations are rare in fetuses with renal agenesis or other severe kidney development defects
}

\author{
Cécile Jeanpierre $^{1,2}$, Guillaume Macé ${ }^{1,2}$, Mélanie Parisot ${ }^{1,2}$, Vincent Morinière ${ }^{3,4}$, Audrey \\ Pawtowsky $^{3}$, Marion Benabou ${ }^{1,2}$, Jelena Martinovic ${ }^{5}$, Jeanne Amiel ${ }^{2,6}$, Tania Attié-Bitach ${ }^{2,6}$, \\ Anne-Lise Delezoide ${ }^{7,8}$, Philippe Loget ${ }^{9}$, Patricia Blanchet ${ }^{10}$, Dominique Gaillard ${ }^{11}$, Marie \\ Gonzales $^{12,13}$, Wassila Carpentier ${ }^{13,14}$, Patrick Nitschke ${ }^{15}$, Frédéric Tores ${ }^{15}$, Laurence \\ Heidet $^{3,4}$, Corinne Antignac ${ }^{1,2,3}$, Rémi Salomon ${ }^{1,2,4,16}$, and the Société Française de \\ Foetopathologie ${ }^{17}$
}

Corresponding author : Cécile Jeanpierre, $\mathrm{PhD}$ Inserm U983, Hôpital Necker, 75015 Paris, France

E-mail : cecile.jeanpierre@inserm.fr

Tel : 33144495103

Fax : 33144490290

${ }^{1}$ Inserm U983, Hôpital Necker, Paris, France ; ${ }^{2}$ Université Paris Descartes, Paris, France ; ${ }^{3}$ AP-HP, Département de Génétique, Hôpital Necker, Paris, France ; ${ }^{4}$ AP-HP, Centre de Référence des Maladies Rénales Héréditaires de l'Enfant et de l'Adulte (MARHEA), Hôpital Necker, Paris, France ; ${ }^{5}$ AP-HP, Service d'Histologie-Embryologie-Cytogénétique, Hôpital Necker, Paris, France ; ${ }^{6}$ Inserm U781, Hôpital Necker, Paris, France ; ${ }^{7}$ AP-HP, Service de Biologie du développement, Hôpital Robert Debré, Paris, France ; ${ }^{8}$ Université Paris Diderot, Paris, France ; ${ }^{9}$ Département d'Anatomie et de Cytologie Pathologiques, Centre Hospitalier de Pontchaillou, Rennes, France ; ${ }^{10}$ Service de Génétique et de Foetopathologie, Hôpital Arnaud de Villeneuve, Montpellier, France; ${ }^{11}$ Service de Génétique, Centre Hospitalier Universitaire de Reims, Inserm U514, Reims, France ; ${ }^{12}$ AP-HP, Service de Génétique et Embryologie médicales, Hôpital Armand Trousseau, Paris, France ; ${ }^{13}$ Université Paris Pierre et Marie Curie, Paris, France ; ${ }^{14}$ Plateforme Post-Génomique P3S, Hôpital Pitié-Salpêtrière, Paris, France ; ${ }^{15}$ Plateforme de Bioinformatique de l'Université Paris Descartes, Paris, France ${ }^{16}$ AP-HP, Service de Néphrologie Pédiatrique, Hôpital Necker, Paris, France. ${ }^{17}$ The members of the Société Française de Foetopathologie who provided fetal tissues are : E Alanio, CHU Reims; J Aziza, CHU Toulouse; B Bessières, Institut de Puériculture, Paris; N Bigi, CHU Montpellier; M-H Saint Frison, CH Victor Dupouy, Argenteuil; R Bouvier, Centre de Pathologie Est, Bron; M Bucourt, Hôpital Jean Verdier, Bondy; D Carles, CHU Pellegrin, 
Bordeaux; A Clemenson, CHU St Etienne; F Cornelis, Hôpital Jean Verdier, Bondy; F Dijoud, Hôpital de la Croix Rousse, Lyon; O.Esperandieu, CH Orléans; B Foliguet, CHU Nancy; F Guimiot, Hôpital Robert Debré, Paris; V Hennequin, CHU Nancy; S KhungSavatovsky, Hôpital Robert Debré, Paris; N Laurent, CHU Dijon; L Loeuillet, CHI Poissy; P Marcorelles, CHU Brest; A-E Mas, Hôpital A. Béclère, Clamart; J-P Masutti, CHU Nancy; M-J Perez, CHU Montpellier; I Pommepuy, CHU Limoges; M Sinico, CHI Créteil; J Tantau, Groupe hospitalier Cochin-St Vincent de Paul, Paris.

Key words: renal agenesis; renal hypodysplasia; variants ; evolutionary conserved non-coding regions ; CNVs

Word count : 3655 


\section{ABSTRACT}

Background The RET/GDNF signalling pathway plays a crucial role during development of kidneys and enteric nervous system. In humans, RET activating mutations cause multiple endocrine neoplasia, whereas inactivating mutations are responsible for Hirschsprung disease. RET mutations have also been reported in fetuses with renal agenesis, based on analysis of a small series of samples.

Objective and Methods To better characterize the involvement of RET and GDNF in kidney development defects, we studied a series of 105 fetuses with bilateral defects including renal agenesis, severe hypodysplasia or multicystic dysplastic kidney. RET and GDNF coding sequences, evolutionary conserved non-coding regions (ECRs) in promoters, 3'UTRs and RET intron 1 were analysed. Copy number variations (CNVs) at these loci were also investigated.

Results We identified: (i) a low frequency $(<7 \%)$ of potential mutations in the RET coding sequence, with inheritance from the healthy father for four of them; (ii) no GDNF mutation; (iii) similar allele frequencies in patients and controls for most SNP variants, except for RET intron 1 variant rs2506012 that was significantly more frequent in affected fetuses than in controls (6\% vs. $2 \%, P=0.01$ ); (iv) distribution of the few rare $R E T$ variants unidentified in controls into the various 5'-ECRs; (v) absence of CNVs.

Conclusion These results suggest that genomic alteration of RET or GDNF is not a major mechanism leading to renal agenesis and other severe kidney development defects. Analysis of a larger series of patients will be necessary to validate the association of the RET intron 1 variant rs2506012 with renal development defects. 


\section{INTRODUCTION}

Congenital abnormalities of the kidney and urinary tract (CAKUT) are frequently observed in children and represent a significant cause of morbidity, accounting for more than $40 \%$ of pediatric end-stage renal failure, and mortality.[1] Kidney development defects (KDD) include: (i) bilateral/unilateral renal agenesis (BRA/URA); (ii) renal hypodysplasia (RHD) characterized by a reduction in the number of nephrons leading to a small overall kidney size and frequent dysplasia with or without cysts; and (iii) multicystic dysplastic kidney (MCDK). These various alterations can be observed together in a same patient or in different members of the same family, suggesting that they belong to a same continuum of phenotypes. Although most cases are sporadic and isolated, syndromic and familial cases suggest that genetic factors are involved. In particular, dominant mutations with variable penetrance have been found in several syndromic forms of KDD. The most frequently mutated genes are $P A X 2$ in patients with renal-coloboma syndrome, EYAI and SIXI in patients with branchio-oto-renal (BOR) syndrome and $H N F 1 B$ in patients with renal cysts and diabetes association.[2-6] Analysis of genotype-phenotype correlations showed that the severity of the renal disease associated with these mutations is extremely variable.[2,7] Other less frequent syndromes including KDD are associated with mutations in developmental genes such as SALL1 (Townes-Brocks syndrome), WNT4 (Rokitanski syndrome), KAL1 (Kallman syndrome), FRAS1 and FREM1 (Fraser syndrome), GATA3 (RHD, hypoparathyroidism and sensorineural deafness) and GLI3 (Pallister-Hall syndrome).[8-14] Moreover, comparative genomic hybridization and familial studies have highlighted several chromosomal regions that could carry other genes involved in KDD.[15,16].

Mammalian kidney development results from a reciprocal induction between the ureteric bud (UB) and the metanephric mesenchyme (MM). Signalling by GDNF secreted by the MM and the RET tyrosine kinase receptor and its co-receptor GFR $\alpha 1$ expressed on the UB plays a critical role for normal growth and branching of the UB.[17,18] The RET gene encodes two major splicing isoforms, RET9 and RET51, that differ in their carboxy terminus. These two isoforms appear to have redundant roles for kidney development.[19,20] The RET/GDNF signalling also plays a critical role during the development of the enteric nervous system. Homozygous knockout of Ret or Gdnf in mice leads to loss of enteric ganglia as well as severe kidney aplasia or hypodysplasia caused by a failure of UB outgrowth.[21,22] In humans, heterozygous loss-of-function mutations in RET resulting in haploinsufficiency are the most frequent alterations reported in patients with segmental intestinal aganglionosis known as Hirschsprung disease (HSCR).[23,24] RET is also an oncogene involved, through 
activating mutations, in predisposition to multiple endocrine neoplasia type 2A (MEN2A) characterized by medullary thyroid carcinoma (MTC), pheochromocytoma and/or parathyroid hyperplasia.[25] Several studies have reported the association of HSCR and MTC in patients with RET mutations affecting the cysteine-rich extracellular domain of the protein. Both activating and inactivating effects have been demonstrated for the C620R mutation (so called the Janus mutation) because, when expressed in kidney cells, it promotes cell proliferation and impairs migration and branching in three-dimensional culture in response to GDNF.[26] Interestingly, association of HSCR with CAKUT has also been described and a RET mutation has been reported in few cases,[27] suggesting a common genetic basis for these two pathologies. Renal agenesis was also reported in a family with MTC and the Janus RET C620 mutation.[28] Recently, both activating and inactivating RET mutations have been reported in a small series of fetuses with renal agenesis.[29]

To better assess the role of the RET/GDNF signalling in KDD, we analysed coding and regulatory sequences of $R E T$ and $G D N F$ in a series of 105 fetuses with severe bilateral defects.

\section{PATIENTS AND METHODS}

\section{Patients}

We studied a series of 105 fetuses with bilateral KDD contributing to anamnios or severe oligohydramnios and that had motivated termination of pregnancy. This included 65 cases with BRA, 24 cases with URA and an abnormal contralateral kidney (RHD in 8 cases, MCDK in 16 cases), 4 cases with bilateral RHD, 10 cases with bilateral MCDK, one case with RHD on one kidney and MCDK on the other and one case with URA and ureteral duplication. Kidney defects were defined by the fetopathologists of the Société Française de Foetopathologie upon histological examination. Five fetuses were from consanguineous families, 11 cases (including 4 sib-pairs) were from 7 non-consanguineous families in which the mother underwent several terminations of pregnancy for anamnios, and five other cases had relatives with renal abnormalities. Twenty-one fetuses had extra-renal abnormalities, namely uterine agenesis (6 cases), bifid uterus (1 case), epididymal hypoplasia or cysts (2 cases), or more complex syndromic associations (growth retardation, craniofacial dysmorphy, hand and limb anomalies, cardiopathy). No GLI3 mutation was identified in 3 fetuses with symptoms suggestive of Pallister-Hall syndrome. There was no indication of renal-coloboma or BOR syndromes in relatives of any of the studied fetuses. Moreover, we excluded the presence of $H N F 1 B$ mutations / deletions in the fetuses with MCDK or RHD with cysts. 
This study was fully approved by the Comite de Protection des Personnes pour la Recherche Biomédicale Ile de France 2 and informed consent was obtained from all parents. DNA was extracted from frozen liver, lung, spleen or kidney samples. For three fetuses, RNA was also extracted from frozen kidney samples.

\section{Sequencing of $R E T$ and $G D N F$ coding and non-coding sequences}

We screened the 20 RET exons encoding both protein isoforms (RET9: exons 1 to 19b, RET51: exons 1 to 19a, 20) and the three GDNF exons (non-coding exon 1 and coding exons 2 and 3). Evolutionary conserved non-coding regions (ECRs) located upstream of RET and GDNF and in RET intron 1 (http://www.dcode.org) were also analyzed. Their positions relative to exon 1 are given in Table 1. Finally, as variations in the 3'UTR could potentially disrupt genetic regulation by micro-RNAs, these regions were also analyzed. The 3'UTRs of RET9 and RET51 transcripts were identified from http://www.ensembl.org/. For analysis of the 3'UTR of GDNF, we focused on the first $1231 \mathrm{bp}$ that were evolutionary conserved (Table 1). PCR and sequencing primers are available upon request.

Table1 Evolutionary conserved sequences in 5' and 3' of RET and GDNF

\begin{tabular}{|c|c|c|c|c|c|}
\hline $\begin{array}{l}\text { Evolutionary } \\
\text { Conserved } \\
\text { Region }\end{array}$ & $\begin{array}{l}\text { Position on } \\
\text { chromosome }\end{array}$ & $\begin{array}{l}\text { Position } \\
\text { related to the } \\
\text { first exon }\end{array}$ & $\begin{array}{l}\text { Size } \\
\text { (bp) }\end{array}$ & Homology ${ }^{1}$ & $\begin{array}{l}\text { More distant } \\
\text { species with } \\
>70 \% \\
\text { homology }\end{array}$ \\
\hline RET-ECR1E & $\begin{array}{l}\text { chr10:42794983- } \\
42795367\end{array}$ & $5^{\prime}(-97 \mathrm{~kb})$ & 385 & $78 \%(\mathrm{O})$ & chicken \\
\hline RET-ECR1B & $\begin{array}{l}\text { chr10:42803235- } \\
42803698\end{array}$ & $5^{\prime}(-89 \mathrm{~kb})$ & 464 & $78 \%(\mathrm{M})$ & frog \\
\hline RET-ECR1 & $\begin{array}{l}\text { chr10:42880879- } \\
42881488\end{array}$ & $5^{\prime}(-11.6 \mathrm{~kb})$ & 610 & $77 \%(\mathrm{M})$ & chicken \\
\hline RET-ECR4 & $\begin{array}{l}\text { chr10:42883631- } \\
42883905\end{array}$ & $5^{\prime}(-8.9 \mathrm{~kb})$ & 275 & $74 \%(\mathrm{M})$ & mouse \\
\hline RET-ECR8 & $\begin{array}{l}\text { chr10:42883965- } \\
42884464\end{array}$ & $5^{\prime}(-8.5 \mathrm{~kb})$ & 500 & $77 \%(\mathrm{M})$ & mouse \\
\hline RET-ECR2 & $\begin{array}{l}\text { chr10:42886856- } \\
42887495\end{array}$ & $5^{\prime}(-5.7 \mathrm{~kb})$ & 640 & $79 \%(\mathrm{M})$ & opossum \\
\hline RET-ECR6 & $\begin{array}{l}\text { chr10:42895408- } \\
42895741\end{array}$ & intron 1 & 334 & $76 \%(\mathrm{M})$ & mouse/rat \\
\hline RET-ECR7 & $\begin{array}{l}\text { chr10:42902036- } \\
42902350\end{array}$ & intron 1 & 315 & $72 \%(\mathrm{M})$ & opossum \\
\hline GDNF-ECR1 & $\begin{array}{l}\text { chr5:37876398- } \\
37876866\end{array}$ & $5^{\prime}(-5.5 \mathrm{~kb})$ & 469 & $81 \%(\mathrm{O})$ & opossum \\
\hline GDNF-ECR2 & $\begin{array}{l}\text { chr5:37877173- } \\
37877521\end{array}$ & $5^{\prime}(-6.2 \mathrm{~kb})$ & 349 & $75 \%(\mathrm{O})$ & opossum \\
\hline
\end{tabular}


$\begin{array}{lllll}\text { GDNF-ECR3 chr5:37850279- } & \text { 3'-UTR } & 1231 & 82 \%(\mathrm{M}) & \text { opossum }\end{array}$ 37851510

Positions on chromosomes are given according to the NCBI36/hg18 built ;

${ }^{1} \%$ of homology of the selected region with the mouse $(\mathrm{M})$ or the opossum $(\mathrm{O})$ sequence

\section{Statistical analyses}

Fisher exact tests were used to compare frequencies of the variants in patients and controls. As $80 \%$ of the fetuses were of European origin, frequencies in controls were mostly evaluated by analysis of 189 unrelated Caucasians. Algerian and Turkish controls (34 and 33 cases, respectively) were also tested for polymorphisms present in patients originating from these countries. Moreover, we considered frequencies generated from the HapMap-CEU (120 chromosomes), Pilot.1.CEU (72 chromosomes) and AGI_ASAP (74 chromosomes) populations (http://www.ncbi.nlm.nih.gov/projects/SNP/). For statistical study of the RET variant rs2506012, we analysed a second series of 171 patients, including 53 fetuses and 118 living children, with the same spectrum of bilateral KDD as the first series.

\section{Analysis of RET cDNA}

The effect of the c.1353 G>A variant (T451T) on splicing was analysed by RT-PCR, using primers located in exons 6 and 8. Quantitative RT-PCR was performed using the ABsolute Sybr green ROX mix (Thermo Scientific) and GAPDH was used as a control.

\section{Analysis of copy number variations}

For 41 samples, the quality and the available amount of DNA allowed us to perform genomic analysis on Illumina Infinium HumanOmni1 beadchips. Hybridizations were performed as recommended by the manufacturer. We used the GenomeStudio software for normalization and genotyping. For identification of copy number variations (CNVs), we used the GenomeStudio plug-in CNVpartition and the PennCNV algorithm with default parameters.[30]

\section{RESULTS}

\section{Analysis of $R E T$}

Sequencing of the 20 exons of RET in 105 fetuses with severe bilateral KDD identified 7 previously unreported variations in the coding region, including one nonsense mutation, four missense and two neutral changes (Table 2). All variations were heterozygous and none of 
them was identified in 180 controls. The nonsense mutation resulted in a stop codon located 58 and 16 amino acids before the C-terminus of RET51 and RET9 isoforms, respectively. PolyPhen-2 predicted variations D567N and V787I as probably damaging with scores of 0.984 and 0.979 respectively and L56M as possibly damaging with a score of 0.281 . Although R57Q was predicted as benign by PolyPhen-2, it was qualified as possibly damaging with the previous version of PolyPhen (score=1.558) and it affects a very conserved aminoacid.

For fetuses with the R57Q, D567N and W1056X mutations and the P992P neutral variant, DNA from the parents was available. In all four cases, the variation was also present in the heterozygous state in the father, in whom presence of the two normal-sized kidneys was ascertained by renal echography. This demonstrates that none of these variants alone, even the nonsense mutation, is sufficient to explain the renal development defect.

Table 2 Variants identified in the RET coding sequence

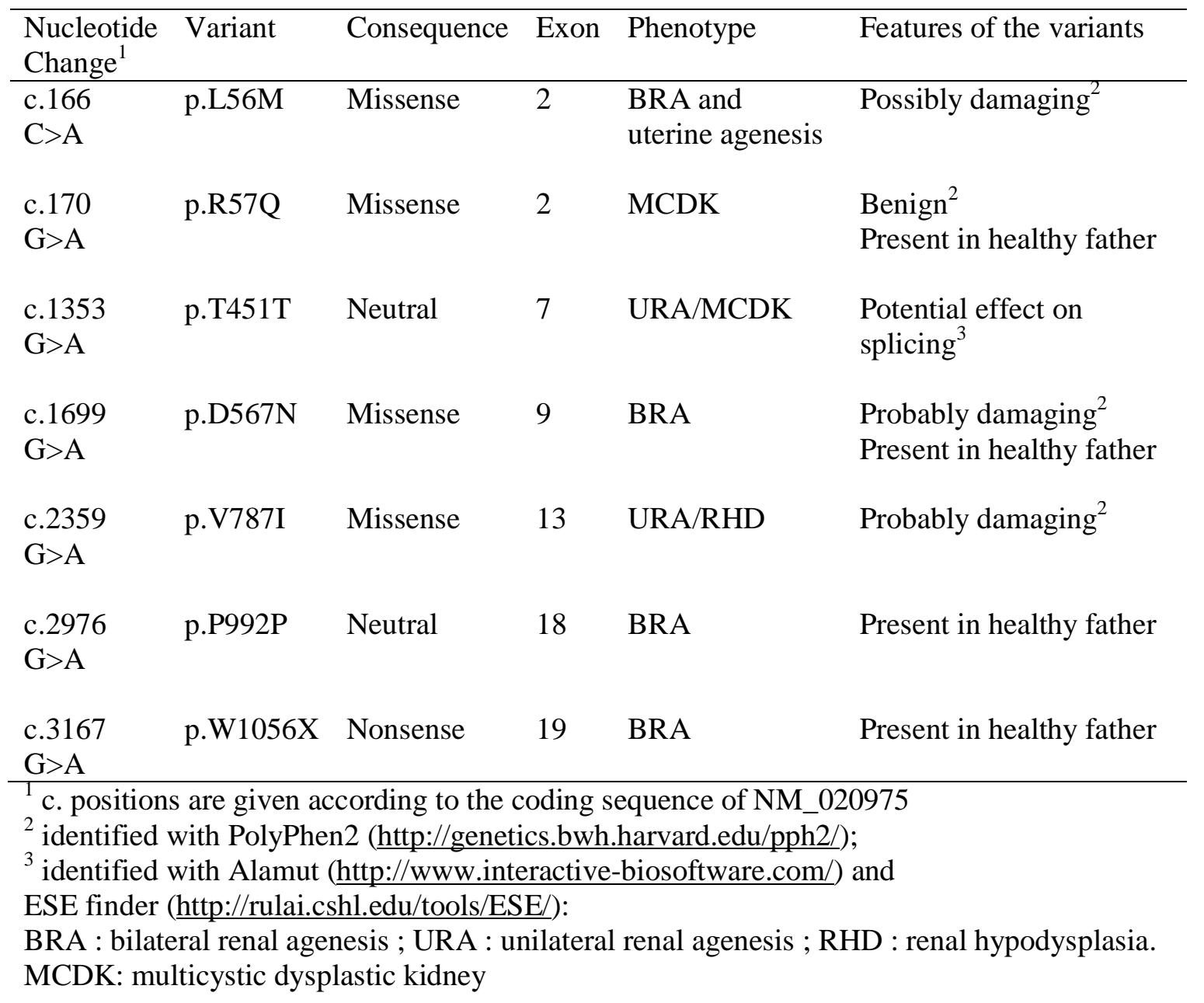


We questioned whether the neutral variations c.1353 G>A (T451T) located in exon 7 and c.2976 G>A (P992P) in exon 18 could have an effect on splicing, using the mutation interpretation software Alamut (http://www.interactive-biosoftware.com/) and the Exonic Splicing Enhancer analysis software ESE finder (http://rulai.cshl.edu/tools/ESE/). While we did not identify any effect of the c.2976 G>A variant, both methods identified creation of sites for splicing factors SF2, SC25 and SPp40 by the c.1353 G>A variant (scores = 4.5, 2.5 and 4.5, respectively), suggesting that this variant might alter splicing of exon 7.[31] To test this hypothesis, we amplified a cDNA fragment spanning RET exons 6 to 8 from kidney samples obtained for fetus H637 with the c.1353 G>A exon 7 variant, two other fetuses with KDD and no RET mutation, and three control fetuses without renal pathologies. We did not identify any abnormal-sized band associated with the variant (data not shown). To analyse if the variant could decrease the amount of RET transcript, we performed quantitative RT-PCR using the same exon 6 and exon 8 primers. In the three KDD kidney samples, the level of RET expression was 10 times lower than in the normal fetal kidney samples. However, RET expression in H637 kidney sample with the c.1353 G>A variant was not different from RET expression in the two other KDD kidney samples without RET mutation (data not shown). Altogether, these results did not allow us to validate any effect of the c.1353 G>A variant on $R E T$ expression. Whether the low level of RET expression in KDD kidneys is a cause or a consequence of the altered kidney development remains an open question.

Several variations corresponding to known SNPs were also identified in the coding sequence as well as in flanking intronic sequences. We compared their frequencies in the KDD fetuses to controls (Table 3A). No significant difference was observed. Evolutionary sequence conservation has proven a valuable approach to identify genomic regions important for gene expression regulation. Using the ECR Browser (http://ecrbrowser.dcode.org), we identified 8 ECR regions that were at least $70 \%$ conserved until mouse (Table 1). Six ECRs were located upstream of the transcript region (ECR1, -1B, -1E, -2, -4 and -8,) and sequencing of these ECRs in the 105 samples led to the identification of 11 variants (Table 3A): five of them were referenced in the SNP database (http://www.ncbi.nlm.nih.gov/snp/) and their frequencies were similar in cases and controls, whereas the 6 other were unreported variations that were heterozygous in $1 \%$ to $6 \%$ of the fetuses (allele frequencies between 0.005 and 0.03). We only identified the most frequent one, ECR2/504, in controls (Table 3A). ECR6 and ECR7 were located in intron 1 and included 7 variants that were all referenced in the SNP database. One of these variants, ECR6/271, was significantly more frequent in the KDD fetuses than in controls (heterozygous in $14 / 96$ fetuses vs $7 / 189$ controls, $P=0.002$ ) 
(Table 3A). To confirm this result, we analysed a new series of 171 cases with bilateral KDD including 53 fetuses and 118 children. Based on analysis of all of the samples (variant heterozygous in a total of 24/267 fetuses/children) or fetuses only (variant heterozygous in a total of 17/149 fetuses), the variant frequency remains significantly higher in cases than in controls ( $P=0.04$ or $P=0.01$, respectively). The presence of the variant in fetuses with BRA but also in fetuses and children with MCDK suggests that it could confer predisposition to the whole spectrum of KDD.

Sequencing of the 3'UTR of both RET9 and RET51 transcriptional isoforms revealed 8 referenced SNPs and 6 previously unreported rare variants (Table 3A). There was no significant difference in their frequencies in cases vs. controls.

Table 3A Polymorphic variants in the RET sequence

\begin{tabular}{|c|c|c|c|c|c|}
\hline & Position & $\begin{array}{l}\text { Variation in } \\
\text { non coding } \\
\text { sequence }\end{array}$ & $\begin{array}{l}\text { Variation } \\
\text { in coding } \\
\text { sequence }\end{array}$ & $\begin{array}{l}\text { Frequency of } \\
\text { the minor } \\
\text { allele in KDD } \\
\text { fetuses } \\
\text { (in controls) }\end{array}$ & $\begin{array}{l}\text { SNP } \\
\text { referenced } \\
\text { in NCBI }\end{array}$ \\
\hline \multirow{11}{*}{ 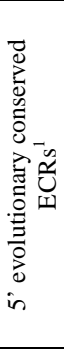 } & ECR1E/83 & $\mathrm{C}>\mathrm{A}$ & & $0.01(-)$ & \multirow[t]{2}{*}{ rs73262104 } \\
\hline & ECR1E/176 & $\mathrm{C}>\mathrm{A}$ & & $0.01(-)$ & \\
\hline & ECR1B/36 & $\mathrm{G}>\mathrm{A}$ & & $0.23(0.23)$ & \multirow[t]{2}{*}{ rs 1547930} \\
\hline & ECR1B/136 & $\mathrm{C}>\mathrm{T}$ & & $0.01(-)$ & \\
\hline & ECR1B/262 & $\mathrm{C}>\mathrm{T}$ & & $0.01(-)$ & \multirow[t]{2}{*}{ rs 12572318} \\
\hline & ECR1B/293 & $\mathrm{G}>\mathrm{A}$ & & $0.005(0.007)$ & \\
\hline & ECR8/48 & $\mathrm{C}>\mathrm{T}$ & & $0.29(0.24)$ & \multirow[t]{2}{*}{ rs7910199 } \\
\hline & ECR2/63 & $\mathrm{T}>\mathrm{C}$ & & $0.005(-)$ & \\
\hline & ECR2/189 & $\mathrm{C}>\mathrm{G}$ & & $0.47(0.51)$ & \multirow[t]{3}{*}{ rs 2505992} \\
\hline & ECR2/230 & delTCAC & & $0.005(-)$ & \\
\hline & ECR2/504 & $\mathrm{C}>\mathrm{T}$ & & $0.03(0.02)$ & \\
\hline \multirow{7}{*}{ 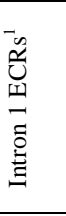 } & ECR6/44 & $\mathrm{G}>\mathrm{A}$ & & $0.09(0.10)$ & rs 1897002 \\
\hline & ECR6/198 & $\mathrm{C}>\mathrm{T}$ & & $0.36(0.37)$ & rs 1864411 \\
\hline & ECR6/213 & $\mathrm{C}>\mathrm{T}$ & & $0.33(0.28)$ & rs 10900298 \\
\hline & ECR6/224 & $\mathrm{G}>\mathrm{T}$ & & $0.20(0.23)$ & rs 1864410 \\
\hline & ECR6/271 & $\mathrm{C}>\mathrm{G}$ & & $0.07(0.02)^{5}$ & rs 2506012 \\
\hline & ECR7/27 & $\mathrm{C}>\mathrm{T}$ & & $0.21(0.19)^{4}$ & rs 2435357 \\
\hline & ECR7/244 & $\mathrm{C}>\mathrm{A}$ & & $0.21(0.18)^{4}$ & rs 2506004 \\
\hline \multirow{24}{*}{ 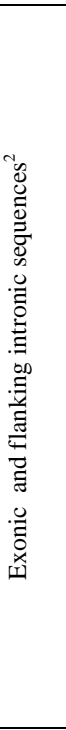 } & c. $73+53$ & $\mathrm{G}>\mathrm{A}$ & & $0.15(0.10)^{3}$ & \multirow[t]{4}{*}{ rs 12267460} \\
\hline & c. $73+104$ & $\mathrm{~T}>\mathrm{C}$ & & 0.005 (nd) & \\
\hline & c. $73+171 / 172$ & $\mathrm{GC}>\mathrm{AA}$ & & $0.30(0.35)$ & \\
\hline & c. $73+173$ & insGGGCGGC & & $0.15(0.10)^{3}$ & \\
\hline & exon2 & & A45A & $0.23(0.29)$ & rs 1800858 \\
\hline & c. $337+9$ & $\mathrm{G}>\mathrm{A}$ & & $0.24(0.28)$ & rs 2435351 \\
\hline & exon3 & & $\mathrm{V} 125 \mathrm{~V}$ & 0.01 (nd) & rs 1800859 \\
\hline & exon3 & & N199N & 0.005 (nd) & rs55810667 \\
\hline & c. $626-72 / 71$ & delCC & & $0.33(0.34)$ & rs35906041 \\
\hline & c. $1264-5$ & $\mathrm{C}>\mathrm{T}$ & & $0.02(0.009)$ & rs9282835 \\
\hline & exon7 & & A432A & $0.31(0.29)$ & rs 1800860 \\
\hline & c. $1648+84$ & $\mathrm{~A}>\mathrm{G}$ & & $0.19(0.22)$ & rs 3026750 \\
\hline & c. $1648+88$ & insC & & $0.19(0.22)$ & rs34827976 \\
\hline & exon11 & & G691S & $0.22(0.22)$ & rs 1799939 \\
\hline & c. $2284+47$ & $\mathrm{C}>\mathrm{T}$ & & $0.28(0.28)$ & rs760466 \\
\hline & c. $2285-102$ & $\mathrm{C}>\mathrm{T}$ & & 0.01 (nd) & \\
\hline & c. $2285-85$ & $\mathrm{G}>\mathrm{A}$ & & 0.005 (nd) & rs 3026766 \\
\hline & exon13 & & L769L & $0.20(0.22)$ & rs 1800861 \\
\hline & exon14 & & S836S & $0.03(0.04)$ & rs 1800862 \\
\hline & c. $2608-24$ & $\mathrm{G}>\mathrm{A}$ & & $0.20(0.21)$ & rs 2472737 \\
\hline & exon15 & & S904S & $0.23(0.26)$ & rs 1800863 \\
\hline & c. $2801+54$ & $\mathrm{~A}>\mathrm{T}$ & & 0.005 (nd) & rs 3026772 \\
\hline & c. $2801+72$ & $\mathrm{G}>\mathrm{A}$ & & 0.005 (nd) & rs 3026773 \\
\hline & exon 18 & & R982C & $0.05(0.03)$ & rs 17158558 \\
\hline
\end{tabular}




\begin{tabular}{|c|c|c|c|c|}
\hline \multirow{4}{*}{ 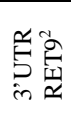 } & c. $3219+15$ & $\mathrm{C}>\mathrm{T}$ & $0.17(0.15)^{4}$ & rs2075912 \\
\hline & c. $3219+128$ & $\mathrm{C}>\mathrm{T}$ & $0.005(-)$ & \\
\hline & c. $3219+166$ & $\mathrm{~A}>\mathrm{T}$ & $0.20(0.22)^{4}$ & rs2075913 \\
\hline & c. $3219+731$ & $\mathrm{C}>\mathrm{T}$ & $0.15(0.15)^{4}$ & rs 2565200 \\
\hline \multirow{10}{*}{ 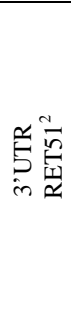 } & c. $3345+29$ & $\mathrm{~A}>\mathrm{C}$ & $0.005(-)$ & \\
\hline & c. $3345+95$ & $\mathrm{C}>\mathrm{T}$ & $0.17(0.22)^{4}$ & rs 17028 \\
\hline & c. $3345+388$ & $\mathrm{G}>\mathrm{A}$ & $0.23(0.13)^{4}$ & rs3026782 \\
\hline & c. $3345+576$ & $\mathrm{G}>\mathrm{A}$ & $0.005(0.003)$ & \\
\hline & c. $3345+600$ & $\mathrm{~T}>\mathrm{A}$ & $0.15(0.19)$ & rs2742240 \\
\hline & c. $3345+1046$ & $\mathrm{G}>\mathrm{C}$ & $0.01(0.003)$ & \\
\hline & c. $3345+1116$ & $\mathrm{~T}>\mathrm{C}$ & $0.20(0.24)$ & rs2435355 \\
\hline & c. $3345+1506$ & $\mathrm{~A}>\mathrm{G}$ & $0.17(0.19)$ & rs2742241 \\
\hline & c. $3345+1582$ & $\mathrm{G}>\mathrm{A}$ & $0.005(-)$ & \\
\hline & c. $3345+1590$ & $\mathrm{G}>\mathrm{A}$ & $0.04(0.03)$ & \\
\hline
\end{tabular}

${ }^{1}$ positions are given according to the ECR sequence (see Table 1);

2 c. positions are given according to NM_020975, except for RET9 3'UTR (NM_020630) ;

${ }^{3}$ frequency of the homozygous variant;

${ }^{4}$ frequency in controls according to Pilot-CEU ;

${ }^{5} \mathrm{p}=0.002$;

(-) absent in controls (370 to 444 chromosomes) ;

(nd) not determined

\section{Analysis of GDNF}

Sequencing of GDNF coding and non-coding sequences identified 7 referenced SNPs and 6 unreported variants (Table 3B). Variant frequencies in the fetuses were not different from those in controls. Therefore, this study did not provide any indication of the involvement of this gene in the etiology of KDD.

Table 3B Polymorphic variants in the GDNF sequence

\begin{tabular}{|c|c|c|c|c|c|}
\hline & Position & $\begin{array}{l}\text { Variation in } \\
\text { non coding } \\
\text { sequence }\end{array}$ & $\begin{array}{l}\text { Variation } \\
\text { in coding } \\
\text { sequence }\end{array}$ & $\begin{array}{l}\text { Frequency of } \\
\text { the minor } \\
\text { allele in KDD } \\
\text { fetuses } \\
\text { (controls) }\end{array}$ & $\begin{array}{l}\text { SNP } \\
\text { referenced } \\
\text { in NCBI }\end{array}$ \\
\hline \multirow{3}{*}{ in } & ECR1/405 & $\mathrm{G}>\mathrm{A}$ & & $0.07(0.11)^{3}$ & rs 2975100 \\
\hline & ECR1/2 & $\mathrm{C}>\mathrm{A}$ & & $0.07(0.22)^{4}$ & rs 2075680 \\
\hline & c. $1-229$ & insGCC & & $0.01(-)$ & \\
\hline \multirow{3}{*}{ 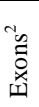 } & c. 150 & $\mathrm{~T}>\mathrm{C}$ & & $0.24(0.33)^{1}$ & rs 2973033 \\
\hline & c. $351+17$ & $\mathrm{C}>\mathrm{T}$ & & $0.005(-)$ & \\
\hline & Exon3 & & R143R & $0.02(0.03)^{5}$ & rs 36010631 \\
\hline \multirow{7}{*}{ 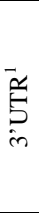 } & ECR3/57 & $\mathrm{G}>\mathrm{T}$ & & 0.005 (nd) & \\
\hline & ECR3/93 & $\mathrm{T}>\mathrm{A}$ & & 0.005 (nd) & rs 45535335 \\
\hline & ECR $3 / 363$ & $\mathrm{~A}>\mathrm{T}$ & & 0.005 (nd) & rs 45611430 \\
\hline & ECR3/450 & $\mathrm{G}>\mathrm{A}$ & & $0.02(0.02)$ & \\
\hline & ECR3/529 & $\mathrm{C}>\mathrm{T}$ & & 0.01 (nd) & rs58787312 \\
\hline & ECR3/795 & $\mathrm{G}>\mathrm{A}$ & & $0.007(-)$ & \\
\hline & ECR3/988 & $\mathrm{T}>\mathrm{C}$ & & $0.05(0.03)$ & \\
\hline \multicolumn{6}{|c|}{$\begin{array}{l}{ }^{1} \text { positions are given according to the ECR sequence (see Tabl } \\
{ }_{2} \text { c. positions are given according to NM_000514; } \\
{ }^{3} \text { frequency in controls according to Pilot-CEU; } \\
{ }^{4} \text { frequency in controls according to JBCI-allele; } \\
5 \text { frequency in controls according to AGI_ASAP population : } \\
\text { (-) absent in controls ( } 296 \text { to } 452 \text { chromosomes); } \\
\text { (nd) not determined }\end{array}$} \\
\hline
\end{tabular}




\section{CNV analysis at RET, GDNF and other genes linked to the RET/GDNF signalling}

Finally, as CNVs could be responsible for an altered gene expression, we quantified the RET and GDNF loci in 41 of the fetuses, based on genomic data generated by DNA hybridization on Illumina HumanOmnil chips. We extended this analysis to several other genes involved in the RET/GDNF pathway, namely the GDNF co-receptor encoding gene GFRA1, regulators of the expression of RET and/or GDNF (GDF11, PAX2, EYA1, SIX1, SIX2, SIX4, HOXA11, HOXD11, FOXC1, GATA3), repressors of the pathway (SPRY1, ROBO2, SLIT2), the activator SOX9 and target genes ETV4 and ETV5.[32-34] For each gene, we analysed not only the gene itself but also surrounding sequences extending up to neighbouring genes on each side, in order to be sure to include regulatory sequences. In addition to two intronic CNVs, in SLIT2 and EYAl, each identified in 4 fetuses, we characterized a $1 \mathrm{~kb}$ heterozygous deletion spanning the GDNF non-coding exon 1 in one case. These three CNVs have been reported in controls (http://projects.tcag.ca/variation/), suggesting that they are polymorphic variations. There was no CNV in any of the other tested genes.

\section{DISCUSSION}

The pattern of expression of RET and GDNF in fetal kidneys, the severe disruption of kidney development in Ret or Gdnf knockout mice, as well as large amounts of data generated from cellular and organ culture models, support the major role of the RET/GDNF signalling in control of branching morphogenesis during kidney development.[17,18,20-22,35-39] Moreover, several RET mutations associated with MTC and/or HSCR have been shown to impair branching in a three-dimensional kidney cell culture model,[26,40] in agreement with a role of RET in kidney morphogenesis. It was thus expected that mutations in RET and GDNF could be responsible for kidney development defects in human. Accordingly, heterozygous RET mutations were previously reported in $30 \%$ of a small series of 29 fetuses with BRA or URA and one heterozygous GDNF mutation in a fetus with URA.[29] However, our results, based on analysis of a larger series of 105 cases including 90 fetuses with either BRA or URA and contralateral RHD or MCDK do not confirm the high frequency of RET mutations in fetuses with renal agenesis or other severe abnormality of kidney development. Discrepancy between the two studies could be explained by differences in the ethnic origin of the patients and/or by a bias due to the small number of patients in the study of Skinner et al.. We only report 7 potential mutations in the RET coding sequence $(6.6 \%)$, and no mutation in the GDNF coding sequence. We did not analyse the sequence of the GDNF co-receptor encoding gene GFRA1 in this study because no mutation has ever been reported in this gene, 
neither in KDD nor in HSCR.[27,29,41] As reported,[29] the RET mutations that we identified in KDD fetuses were heterozygous, distributed all along the gene and most of them were missense variants. Only one nonsense mutation was identified and absence of tissue available for RNA and protein extraction precluded analysis of the impact of this mutation on the expression of the gene. As for HSCR, heterozygosity of the mutations suggests a mechanism based on haploinsufficiency, leading to a dysregulation of the RET signalling in kidney. However, one cannot exclude that some of the missense variants might be activating mutations with both gain-of-function and loss-of-function effects, as suggested for some of the mutations previously described.[29] While Skinner et al. described the presence of two or three mutations in some fetuses, none of the fetuses in our series presented with several mutations.[29] No mutation was common to both studies and only the L56M variant has previously been reported in a HSCR patient.[42] Absence of splicing defect in the kidney from the fetus with the T451T variant suggests that this neutral variant is a rare polymorphism rather than a causative mutation. Moreover, heterozygosity of the P992P variant in a fetus from a consanguineous family and his father suggests that the kidney development defect in this family is probably not linked to this RET variant. Finally, while Skinner et al. did not trace the inherited vs. de novo origin of the mutations in their fetuses, we demonstrate that the missense mutations R57Q and D567N as well as the W1056X nonsense mutation were inherited from healthy fathers. Although we cannot eliminate the hypothesis that somatic mosaicism could explain the absence of phenotype in the father, these results likely indicate that, even if these RET mutations impair kidney development, other genetic or epigenetic events affecting the RET/GDNF signalling must cooperate.

In addition to the 7 RET variations in the coding sequence, a total of 48 SNPs in coding and non-coding RET and GDNF sequences, as well as 21 new rare variants in non-coding sequences were identified in our series of fetuses ( 4 to 22 RET variants per fetus; 0 to 4 GDNF variant per fetus). This includes RET SNP variants A432A in exon 7 and G691S in exon 11, that have been reported as associated with CAKUT,[43,44] and RET variants rs 1864411 , rs 1864410, rs2435357 and rs 2506004 in intron 1 that have been reported as part of a HSCR susceptibility haplotype.[45,46] Based on the observation that allele frequencies in our cases were similar to controls, our data do not support a role in KDD for any of these variants. Four previously unreported variants in RET 5'-ECR regions were identified in a total of six patients and not in controls. However, the absence of clustering of these variants in one specific ECR is not in favour of a role in the dysregulation of RET expression. Moreover, 
discordant genotypes in the 3 pairs of fetuses belonging to families with recurrent KDD suggest that RET is not the culprit gene in these patients.

Interestingly, we identified one polymorphism in RET intron 1 (ECR6/271, rs2506012) with significant over-representation of the minor $G$ allele in KDD fetuses. Analysis of transcription factor binding on the ECR6 sequence using the Genomatix (http://www.genomatix.de) and the Mapper (http://mapper.chip.org) softwares predicted creation of a site for the aryl hydrocarbon receptor nuclear translocator (ARNT) transcription factor by this variant. ARNT is a protein that is involved in translocation of the aryl hydrocarbon receptor (AHR) to the nucleus, following induction by ligands like dioxin and polycyclic aromatic hydrocarbons. Interestingly, ARNT and its receptor AHR are both expressed during kidney development (http://www.gudmap.org/) and activation of AHR has been reported to inhibit branching morphogenesis of metanephric kidneys.[47] Thus, this polymorphism could confer an increased susceptibility to environmental factors and could result in an altered regulation of RET. ARNT has also been identified as the beta subunit of the heterodimeric transcription factor HIF1 (hypoxia-inducible factor 1). As HIF1A is coexpressed with ARNT in cap mesenchyme and UB (http://www.gudmap.org/), an altered regulation of RET by HIF1 can also be proposed. While analysis of a second series of samples confirmed the difference in allele frequencies between KDD fetuses and controls, it resulted in a decrease in the level of significance $(P=0.002$ to $P=0.01)$. Thus, analysis of a larger series of patients will be necessary to unambiguously draw conclusions. Moreover, due to the low frequency of this variant in the fetuses, its potential contribution to kidney development defect can only account for a small proportion of patients.

Quantification of RET transcript in KDD vs. control kidney samples revealed downexpression in the three KDD samples. There are several possible explanations for this result, including sample bias, cause or consequence of the altered differentiation process. One of the mechanisms involved in regulation of gene expression is through binding of micro-RNAs to 3'UTR sequences. Indeed, variations in 3'UTR and mutations in the micro-RNA encoding genes, resulting in an altered gene regulation, have been reported in several pathologies.[4850] In one case, the variation was a common polymorphism, significantly over-represented in patients vs. controls.[51] In the RET gene, a variant located in the 3'UTR has been reported to confer protection from HSCR.[52] However, sequencing of RET and GDNF 3'UTRs in KDD fetuses did not allow us to identify new variants nor variants with a higher frequency in patients vs. controls. When the micro-RNAs that regulate RET expression during kidney development are identified, it will be worthwhile screening for mutations in these sequences. 
Another genetic mechanism that could affect RET and/or GDNF expression and consequently kidney development is gene copy number variations. The only $\mathrm{CNV}$ of potential interest that we identified was a deletion spanning a $\mathrm{CpG}$ rich region and the non-coding exon 1 of GDNF. Although this $\mathrm{CNV}$ has been reported in normal controls (http://projects.tcag.ca/variation/), suggesting that it is a polymorphism, it could result in a decreased GDNF expression. However, it was present in only one fetus and thus cannot be considered as a significant event in KDD. Moreover, CNV analysis of 17 other genes encoding regulators or targets of the RET/GDNF pathway including the GDNF co-receptor encoding gene GFRA1, did not allow us to identify any CNV affecting these genes.

Altogether, this study clearly shows that RET and GDNF genomic alterations are not significantly associated with renal agenesis / hypodysplasia /multicystic dysplastic kidney in humans, suggesting that they play a minor role in KDD. These results are an important issue to be taken into account for genetic diagnosis of these defects. Interestingly, redundant receptor tyrosine kinase signalling, notably including FGF10/FGFR2, as well as a balance between positive and negative regulation of this signalling network, rather than RET/GDNF per se, was suggested to be the central pathway regulating branching for kidney development.[53] Regulatory or target genes common to these redundant signalling events could be worthwhile testing as new candidate genes to explain kidney development defects.

\section{ACKNOWLEDGMENTS}

We thank Dr C Baumann, C. Bernabe-Dupont, B Gilbert, L. Olivier-Faivre and F. Prieur for providing some fetal and/or parental DNAs and Sophie Saunier for helpful discussion.

\section{FOOTNOTES}

Funding This work was supported by Institut National de la Santé et de la Recherche Médicale, Agence Nationale de la Recherche (ANR 06-MPAR-034-01), GIS-Institut des Maladies Rares (AAE07007KSA) and Programme Hospitalier de la Recherche Clinique Assistance Publique (AOM07129).

\section{Competing interest None}

Patients consent obtained

Ethics approval This study was conducted with the approval of the the Comite de Protection des Personnes pour la Recherche Biomédicale Ile de France 2 


\section{REFERENCES}

1. Sanna-Cherchi S, Ravani P, Corbani V, Parodi S, Haupt R, Piaggio G, Innocenti ML, Somenzi D, Trivelli A, Caridi G, Izzi C, Scolari F, Mattioli G, Allegri L, Ghiggeri GM. Renal outcome in patients with congenital anomalies of the kidney and urinary tract. Kidney Int 2009;76:528-33.

2. Heidet L, Decramer S, Pawtowski A, Moriniere V, Bandin F, Knebelmann B, Lebre AS, Faguer S, Guigonis V, Antignac C, Salomon R. Spectrum of HNF1B mutations in a large cohort of patients who harbor renal diseases. Clin J Am Soc Nephrol 2010;5:1079-90.

3. Kochhar A, Orten DJ, Sorensen JL, Fischer SM, Cremers CW, Kimberling WJ, Smith RJ. SIX1 mutation screening in 247 branchio-oto-renal syndrome families: a recurrent missense mutation associated with BOR. Hum Mutat 2008;29:565.

4. Orten DJ, Fischer SM, Sorensen JL, Radhakrishna U, Cremers CW, Marres HA, Van Camp G, Welch KO, Smith RJ, Kimberling WJ. Branchio-oto-renal syndrome (BOR): novel mutations in the EYA1 gene, and a review of the mutational genetics of BOR. Hum Mutat 2008;29:537-44.

5. Ulinski T, Lescure S, Beaufils S, Guigonis V, Decramer S, Morin D, Clauin S, Deschenes G, Bouissou F, Bensman A, Bellanne-Chantelot C. Renal phenotypes related to hepatocyte nuclear factor-1beta (TCF2) mutations in a pediatric cohort. $J$ Am Soc Nephrol 2006;17:497-503.

6. Weber S, Moriniere V, Knuppel T, Charbit M, Dusek J, Ghiggeri GM, Jankauskiene A, Mir S, Montini G, Peco-Antic A, Wuhl E, Zurowska AM, Mehls O, Antignac C, Schaefer F, Salomon R. Prevalence of mutations in renal developmental genes in children with renal hypodysplasia: results of the ESCAPE study. J Am Soc Nephrol 2006;17:2864-70.

7. Krug P, Moriniere V, Marlin S, Koubi V, Gabriel HD, Colin E, Bonneau D, Salomon R, Antignac C, Heidet L. Mutation screening of the EYA1, SIX1 and SIX5 genes in a large cohort of patients harboring branchio-oto-renal syndrome calls into question the pathogenic role of SIX5 mutations. Hum Mutat 2010.

8. Alazami AM, Shaheen R, Alzahrani F, Snape K, Saggar A, Brinkmann B, Bavi P, AlGazali LI, Alkuraya FS. FREM1 mutations cause bifid nose, renal agenesis, and anorectal malformations syndrome. Am J Hum Genet 2009;85:414-8.

9. Biason-Lauber A, Konrad D, Navratil F, Schoenle EJ. A WNT4 mutation associated with Mullerian-duct regression and virilization in a 46,XX woman. $N$ Engl J Med 2004;351:792-8.

10. Botzenhart EM, Bartalini G, Blair E, Brady AF, Elmslie F, Chong KL, Christy K, Torres-Martinez W, Danesino C, Deardorff MA, Fryns JP, Marlin S, Garcia-Minaur S, Hellenbroich Y, Hay BN, Penttinen M, Shashi V, Terhal P, Van Maldergem L, Whiteford ML, Zackai E, Kohlhase J. Townes-Brocks syndrome: twenty novel SALL1 mutations in sporadic and familial cases and refinement of the SALL1 hot spot region. Hum Mutat 2007;28:204-5.

11. Cain JE, Islam E, Haxho F, Chen L, Bridgewater D, Nieuwenhuis E, Hui CC, Rosenblum ND. GLI3 repressor controls nephron number via regulation of Wnt11 and Ret in ureteric tip cells. PLoS One 2009;4:e7313.

12. Georgopoulos NA, Koika V, Galli-Tsinopoulou A, Spiliotis BE, Adonakis G, Keramida MK, Sgourou A, Koufogiannis KD, Papachatzopoulou A, Papavassiliou AG, Kourounis G, Vagenakis GA. Renal dysgenesis and KAL1 gene defects in patients with sporadic Kallmann syndrome. Fertil Steril 2007;88:1311-7. 
13. Pitera JE, Scambler PJ, Woolf AS. Fras1, a basement membrane-associated protein mutated in Fraser syndrome, mediates both the initiation of the mammalian kidney and the integrity of renal glomeruli. Hum Mol Genet 2008;17:3953-64.

14. Van Esch H, Groenen P, Nesbit MA, Schuffenhauer S, Lichtner P, Vanderlinden G, Harding B, Beetz R, Bilous RW, Holdaway I, Shaw NJ, Fryns JP, Van de Ven W, Thakker RV, Devriendt K. GATA3 haplo-insufficiency causes human HDR syndrome. Nature 2000;406:419-22.

15. Sanna-Cherchi S, Caridi G, Weng PL, Dagnino M, Seri M, Konka A, Somenzi D, Carrea A, Izzi C, Casu D, Allegri L, Schmidt-Ott KM, Barasch J, Scolari F, Ravazzolo R, Ghiggeri GM, Gharavi AG. Localization of a gene for nonsyndromic renal hypodysplasia to chromosome 1p32-33. Am J Hum Genet 2007;80:539-49.

16. Weber S, Landwehr C, Renkert M, Hoischen A, Wuhl E, Denecke J, Radlwimmer B, Haffner D, Schaefer F, Weber RG. Mapping candidate regions and genes for congenital anomalies of the kidneys and urinary tract (CAKUT) by array-based comparative genomic hybridization. Nephrol Dial Transplant 2010.

17. Chi X, Michos O, Shakya R, Riccio P, Enomoto H, Licht JD, Asai N, Takahashi M, Ohgami N, Kato M, Mendelsohn C, Costantini F. Ret-dependent cell rearrangements in the Wolffian duct epithelium initiate ureteric bud morphogenesis. Dev Cell 2009;17:199-209.

18. Meyer TN, Schwesinger C, Bush KT, Stuart RO, Rose DW, Shah MM, Vaughn DA, Steer DL, Nigam SK. Spatiotemporal regulation of morphogenetic molecules during in vitro branching of the isolated ureteric bud: toward a model of branching through budding in the developing kidney. Dev Biol 2004;275:44-67.

19. de Graaff E, Srinivas S, Kilkenny C, D'Agati V, Mankoo BS, Costantini F, Pachnis V. Differential activities of the RET tyrosine kinase receptor isoforms during mammalian embryogenesis. Genes Dev 2001;15:2433-44.

20. Jain S, Encinas M, Johnson EM, Jr., Milbrandt J. Critical and distinct roles for key RET tyrosine docking sites in renal development. Genes Dev 2006;20:321-33.

21. Sanchez MP, Silos-Santiago I, Frisen J, He B, Lira SA, Barbacid M. Renal agenesis and the absence of enteric neurons in mice lacking GDNF. Nature 1996;382:70-3.

22. Schuchardt A, D'Agati V, Larsson-Blomberg L, Costantini F, Pachnis V. Defects in the kidney and enteric nervous system of mice lacking the tyrosine kinase receptor Ret. Nature 1994;367:380-3.

23. Angrist M, Bolk S, Thiel B, Puffenberger EG, Hofstra RM, Buys CH, Cass DT, Chakravarti A. Mutation analysis of the RET receptor tyrosine kinase in Hirschsprung disease. Hum Mol Genet 1995;4:821-30.

24. Attie T, Pelet A, Edery P, Eng C, Mulligan LM, Amiel J, Boutrand L, Beldjord C, Nihoul-Fekete C, Munnich A, et al. Diversity of RET proto-oncogene mutations in familial and sporadic Hirschsprung disease. Hum Mol Genet 1995;4:1381-6.

25. Margraf RL, Crockett DK, Krautscheid PM, Seamons R, Calderon FR, Wittwer CT, Mao R. Multiple endocrine neoplasia type 2 RET protooncogene database: repository of MEN2-associated RET sequence variation and reference for genotype/phenotype correlations. Hum Mutat 2009;30:548-56.

26. Arighi E, Popsueva A, Degl'Innocenti D, Borrello MG, Carniti C, Perala NM, Pierotti MA, Sariola H. Biological effects of the dual phenotypic Janus mutation of ret cosegregating with both multiple endocrine neoplasia type 2 and Hirschsprung's disease. Mol Endocrinol 2004;18:1004-17.

27. Pini Prato A, Musso M, Ceccherini I, Mattioli G, Giunta C, Ghiggeri GM, Jasonni V. Hirschsprung disease and congenital anomalies of the kidney and urinary tract (CAKUT): a novel syndromic association. Medicine (Baltimore) 2009;88:83-90. 
28. Lore F, Di Cairano G, Talidis F. Unilateral renal agenesis in a family with medullary thyroid carcinoma. N Engl J Med 2000;342:1218-9.

29. Skinner MA, Safford SD, Reeves JG, Jackson ME, Freemerman AJ. Renal aplasia in humans is associated with RET mutations. Am J Hum Genet 2008;82:344-51.

30. Wang K, Li M, Hadley D, Liu R, Glessner J, Grant SF, Hakonarson H, Bucan M. PennCNV: an integrated hidden Markov model designed for high-resolution copy number variation detection in whole-genome SNP genotyping data. Genome Res 2007; 17:1665-74.

31. Cartegni L, Chew SL, Krainer AR. Listening to silence and understanding nonsense: exonic mutations that affect splicing. Nat Rev Genet 2002;3:285-98.

32. Little M, Georgas K, Pennisi D, Wilkinson L. Kidney development: two tales of tubulogenesis. Curr Top Dev Biol 2010;90:193-229.

33. Lu BC, Cebrian C, Chi X, Kuure S, Kuo R, Bates CM, Arber S, Hassell J, MacNeil L, Hoshi M, Jain S, Asai N, Takahashi M, Schmidt-Ott KM, Barasch J, D'Agati V, Costantini F. Etv4 and Etv5 are required downstream of GDNF and Ret for kidney branching morphogenesis. Nat Genet 2009;41:1295-302.

34. Reginensi A, Clarkson M, Neirijnck Y, Lu B, Ohyama T, Groves AK, Sock E, Wegner M, Costantini F, Chaboissier MC, Schedl A. SOX9 controls epithelial branching by activating RET effector genes during kidney development. Hum Mol Genet 2011.

35. Jain S, Knoten A, Hoshi M, Wang H, Vohra B, Heuckeroth RO, Milbrandt J. Organotypic specificity of key RET adaptor-docking sites in the pathogenesis of neurocristopathies and renal malformations in mice. J Clin Invest 2010;120:778-90.

36. Jijiwa M, Fukuda T, Kawai K, Nakamura A, Kurokawa K, Murakumo Y, Ichihara M, Takahashi M. A targeting mutation of tyrosine 1062 in Ret causes a marked decrease of enteric neurons and renal hypoplasia. Mol Cell Biol 2004;24:8026-36.

37. Majumdar A, Vainio S, Kispert A, McMahon J, McMahon AP. Wnt11 and Ret/Gdnf pathways cooperate in regulating ureteric branching during metanephric kidney development. Development 2003;130:3175-85.

38. Shakya R, Watanabe T, Costantini F. The role of GDNF/Ret signaling in ureteric bud cell fate and branching morphogenesis. Dev Cell 2005;8:65-74.

39. Srinivas S, Wu Z, Chen CM, D'Agati V, Costantini F. Dominant effects of RET receptor misexpression and ligand-independent RET signaling on ureteric bud development. Development 1999;126:1375-86.

40. Degl'Innocenti D, Arighi E, Popsueva A, Sangregorio R, Alberti L, Rizzetti MG, Ferrario C, Sariola H, Pierotti MA, Borrello MG. Differential requirement of Tyr1062 multidocking site by RET isoforms to promote neural cell scattering and epithelial cell branching. Oncogene 2004;23:7297-309.

41. Myers SM, Salomon R, Goessling A, Pelet A, Eng C, von Deimling A, Lyonnet S, Mulligan LM. Investigation of germline GFR alpha-1 mutations in Hirschsprung disease. J Med Genet 1999;36:217-20.

42. Hofstra RM, Wu Y, Stulp RP, Elfferich P, Osinga J, Maas SM, Siderius L, Brooks AS, vd Ende JJ, Heydendael VM, Severijnen RS, Bax KM, Meijers C, Buys CH. RET and GDNF gene scanning in Hirschsprung patients using two dual denaturing gel systems. Hum Mutat 2000;15:418-29.

43. Yang Y, Houle AM, Letendre J, Richter A. RET Gly691Ser mutation is associated with primary vesicoureteral reflux in the French-Canadian population from Quebec. Hum Mutat 2008;29:695-702.

44. Zhang Z, Quinlan J, Hoy W, Hughson MD, Lemire M, Hudson T, Hueber PA, Benjamin A, Roy A, Pascuet E, Goodyer M, Raju C, Houghton F, Bertram J, Goodyer 
P. A common RET variant is associated with reduced newborn kidney size and function. J Am Soc Nephrol 2008;19:2027-34.

45. Burzynski GM, Nolte IM, Bronda A, Bos KK, Osinga J, Plaza Menacho I, Twigt B, Maas S, Brooks AS, Verheij JB, Buys CH, Hofstra RM. Identifying candidate Hirschsprung disease-associated RET variants. Am J Hum Genet 2005;76:850-8.

46. Pelet A, de Pontual L, Clement-Ziza M, Salomon R, Mugnier C, Matsuda F, Lathrop M, Munnich A, Feingold J, Lyonnet S, Abel L, Amiel J. Homozygosity for a frequent and weakly penetrant predisposing allele at the RET locus in sporadic Hirschsprung disease. J Med Genet 2005;42:e18.

47. Falahatpisheh MH, Ramos KS. Ligand-activated Ahr signaling leads to disruption of nephrogenesis and altered Wilms' tumor suppressor mRNA splicing. Oncogene 2003;22:2160-71.

48. Mencia A, Modamio-Hoybjor S, Redshaw N, Morin M, Mayo-Merino F, Olavarrieta L, Aguirre LA, del Castillo I, Steel KP, Dalmay T, Moreno F, Moreno-Pelayo MA. Mutations in the seed region of human miR-96 are responsible for nonsyndromic progressive hearing loss. Nat Genet 2009;41:609-13.

49. Simon D, Laloo B, Barillot M, Barnetche T, Blanchard C, Rooryck C, Marche M, Burgelin I, Coupry I, Chassaing N, Gilbert-Dussardier B, Lacombe D, Grosset C, Arveiler B. A mutation in the 3'-UTR of the HDAC6 gene abolishing the posttranscriptional regulation mediated by hsa-miR-433 is linked to a new form of dominant X-linked chondrodysplasia. Hum Mol Genet 2010;19:2015-27.

50. Yang Z, Kaye DM. Mechanistic insights into the link between a polymorphism of the 3'UTR of the SLC7A1 gene and hypertension. Hum Mutat 2009;30:328-33.

51. Yang Z, Venardos K, Jones E, Morris BJ, Chin-Dusting J, Kaye DM. Identification of a novel polymorphism in the 3'UTR of the L-arginine transporter gene SLC7A1: contribution to hypertension and endothelial dysfunction. Circulation 2007;115:126974.

52. Griseri P, Lantieri F, Puppo F, Bachetti T, Di Duca M, Ravazzolo R, Ceccherini I. A common variant located in the 3'UTR of the RET gene is associated with protection from Hirschsprung disease. Hum Mutat 2007;28:168-76.

53. Michos O, Cebrian C, Hyink D, Grieshammer U, Williams L, D'Agati V, Licht JD, Martin GR, Costantini F. Kidney development in the absence of Gdnf and Spry1 requires Fgf10. PLoS Genet 2010;6:e1000809.

"The Corresponding Author has the right to grant on behalf of all authors and does grant on behalf of all authors, an exclusive licence (or non exclusive for government employees) on a worldwide basis to the BMJ Publishing Group Ltd to permit this article (if accepted) to be published in JMG and any other BMJPGL products and sublicences such use and exploit all subsidiary rights, as set out in our licence (http://group.bmj.com/products/journals/instructions-for-authors/licence-forms)." 